Noman 2020, 38(1), 63-74

Revista de Psicologia, Ciències de l'Eduació i de l'Esport

ISSN: $1138-3194$

CFacultat de Psicologia, Ciències de l'Educació i de l’Esport Blanquerna

Universitat Ramon Llull

(c) (i) $\$$

\title{
The digital competence of university students: a systematic literature review
}

\author{
Anna Sánchez-Caballé ${ }^{*}$, Mercè Gisbert-Cervera ${ }^{1} \&$ Francesc Esteve-Mon $^{2}$ \\ 'Department of Pedagogy, Rovira i Virgili University, Tarragona, Spain \\ 2Department of Pedagogy, Jaume I University, Castelló, Spain
}

Received: 2019-07-08

Accepted:2020-03-11

The digital competence of university students: a systematic literature review

Summary. Digital competence is a pressing need for students in the 21st century. The present study is a systematic review of the literature on university students' digital abilities. The methodology consisted of selecting documents $(n=126)$ from three different databases (Scopus, Web of Science and ERIC) via peer review. The documents were selected for inclusion following predefined criteria and then analysed using a qualitative analysis software (ATLAS.ti). Digital competence is made up of several elements (information skills, content creation, communication, ethical skills, problem solving, technical skills/use and strategic skills). We identified that the most frequently-used terms in the literature are digital literacy and digital competence. However, the terminology used varies among authors. We also found that most authors do not believe that young people actually have the digital abilities that they are assumed to have. In other words, students do not have a high level of digital competence. Educational institutions therefore need to help them to develop this competence, which is so necessary in the context of $21^{\text {st }}$ century education.

Keywords: digital competence; digital literacy; university; higher education; systematic literature review

La competència digital dels estudiants universitaris: una revisió sistemàtica de la literatura

Resum. La competència digital és imprescindible pels estudiants del segle XXI. L'estudi que es presenta a continuació és una revisió sistemàtica de la literatura sobre les habilitats digitals dels estudiants universitaris. La metodologia va consistir en la selecció de documents $(n=126)$ procedents de tres bases de dades diferents (Scopus, Web of Science i ERIC) mitjançant un procés de revisió per parells. Els documents van ser seleccionats per a la seva inclusió en el procés de recerca seguint criteris predefinits i després es van analitzar mitjançant programari d'anàlisi qualitatiu (ATLAS.ti). Amb l'anàlisi realitzat es va observar que els autors consideren que la competència digital està integrada de diversos elements (habilitats informacionals, creació de contingut, comunicació, habilitats ètiques, resolució de problemes, habilitats /ús tècnic $i$ habilitats estratègiques). Pel que fa a la terminologia que aquest empren per referir-se a aquesta competència s'observa que els termes més utilitzats en la literatura són alfabetització digital i competència digital. Finalment, en referència la CD dels joves la majoria d'autors no consideren que els joves tinguin realment les capacitats digitals que ells consideren que tenen. És a dir, els estudiants no tenen molt desenvolupada la competència digital. Per tant, les institucions educatives els han d'ajudar a desenvolupar-la.

Paraules clau: competència digital; literacitat digital; universitat; educació superior; revisió sistemàtica de literatura

\author{
Correspondence \\ Anna Sánchez-Caballé* \\ anna.sanchez@urv.cat \\ ORCID: 0000-0003-1462-3359 \\ Laboratori d'Aplicacions de Tecnologia a l'Educació \\ Universitat Rovira i Virgili \\ Facultat de Ciències de l'Educació i Psicologia \\ Carretera de Valls s/n \\ 43007 Tarragona
}




\section{Introduction}

Society has undergone many social, economic and cultural changes over the past decade, and young people must be trained to deal with the new reality. Information and communication technology (ICT) has impacted all areas of human activity. The process of digitization of many everyday activities that started in the late $20^{\text {th }}$ century and has only picked up pace in the $21^{\text {st }}$ has obliged citizens to adopt new strategies.

As far back as 2001, Prensky had already coined the expression "digital natives" to refer to those who had grown up in the contemporary technological context. Some years later, in 2007, he also said that those students were quick to learn how to use and apply technology. Other authors have questioned this, however, positing that these skills often correspond only to leisure and socialization activities and are not transferred to academic and employment contexts (Bullen, Morgan, Belfer \& Qayyum, 2009; Gallardo-Echenique, Marqués-Molías, Bullen \& Strijbo, 2015; Kennedy et al., 2009).

Regardless of whether young people do indeed have such skills, there is a consensus in a range of disciplines and institutions that every citizen today should have a certain level of generic digital skills in order to thrive in society (Gisbert, González \& Esteve, 2016). The European Commission created the 2.1 version of the DigComp framework, which is one of the most popular frameworks worldwide. According to that framework, Digital Competence includes five areas: (1) information and data literacy; (2) communication and collaboration; (3) digital content creation; (4) safety; and (5) problem solving (Carretero, Vuorikari \& Punie, 2017). Meanwhile, the same institution has also underlined that the ubiquity of digital devices and the importance of fostering digitally competent students place the onus on educators to develop their own digital competence. To this end, they created the DigCompEdu framework. According to thid document, education professionals need three kinds of digital competences: (1) professional competences; (2) pedagogical competences; and (3) learners' competences (Redecker \& Punie, 2017).

The OECD (2018) argues that in these times of digital transformation, digital literacy is an indispensable condition for mental health. ICT can play an important role in students' personal and professional development. With this in mind, we have undertaken this systematic review of the literature on this subject. Researchers in the various fields that study the issue have referred to the concept of digital competence (DC) using a range of terms and is broken in down into differing lists of components. Our main intention is to take into account these multiple perspectives as we review the subject scientifically. The paper first investigates the terminology used and the different elements included. Next it focuses on the types of papers published on DC. Finally, it discusses whether or not innate abilities in this area exist and how digital skills are developed.

\section{Present study}

The goal of the present review is to study the evolution of the concept of DC in relation to university students, showing how the situation has changed from the earliest published works until today. The intention is to provide an overview of the situation, centred mainly on students and the development of these abilities. The term 'digital competence' will be used throughout the review as an umbrella term for all the labels used in the literature to refer to the various digital skills. The research questions for this study are:

RQ1. What terminology is used to describe DC in higher education, and what elements does it consist of? RQ2: What DC-related profile do students have? RQ3. How is DC developed?

\section{Method}

\section{Systematic literature review}

In order to answer the above questions, we propose a systematic literature review. This is a theoretical construct whose sole purpose is to review the relevant documents in the field, regardless of access to any primary data. It is different from a narrative review, which is non-systematic and therefore cannot be considered a formal research process, but rather a scientific literature format based on opinion (González, Urrútia \& Alonso-Coello, 2011). In short, a systematic literature review is a theoretical construction process whose sole purpose is to review the relevant documents in the field obtained from various relevant databases (Okoli \& Schabram, 2010; Vangrieken, Dochy, Raes, \& Kyndt, 2015).

The study originally set its search parameters to collect literature published from the 1990s to 2017. However, it's important to highlight that after the selection process the oldest document included is from 2006. The focus is on the DC of university students, and the search terms chosen were two keywords related to digital skills and two related to educational level. The search was carried out integrating the Boolean operators as follows: "(digital competence" OR "digital literacy") AND ("higher education" OR "university")'. The online databases consulted for this review were the three most important in terms of scientific publications: (1) the ISI Web of Science, (2) SCOPUS, and (3) the Educational Resources Information Center (ERIC).

\section{Inclusion criteria and selection process}

A five-stage selection process was carried out: (1) initial search and creation of a dataset, during which a search was carried out for documents in the three databases selected using the keywords indicated above, (2) docu- 
ment selection by title via peer review, whereby three researchers selected by title those documents that they considered appropriate and excluded those they did not, (3) document selection by abstract via peer review, whereby documents were selected using the same technique as in the preceding stage, (4) location and download of the selected documents, and (5) exclusion of duplicates and non-corresponding documents, whereby the documents gathered from the three databases were collected together and those that did not download completely were excluded, along with duplicates (Figure 1). Throughout the process the term document is used to refer in general to all the types of publications included (articles, book chapters, conference publications, among others).

During stages two and three, the document review process was organized collaboratively in triple review cycles. To carry out this systematic literature review process, we used a categorization table in which the documents were tagged according to their suitability, with each document receiving one of three labels (yes, no, not sure). We selected only those with a minimum of two affirmative votes. The decision as to whether or not a document was suitable was made following the inclusion criteria, i.e. documents were selected mainly on the basis of whether they dealt with the digital competence of university students. To solve the issue

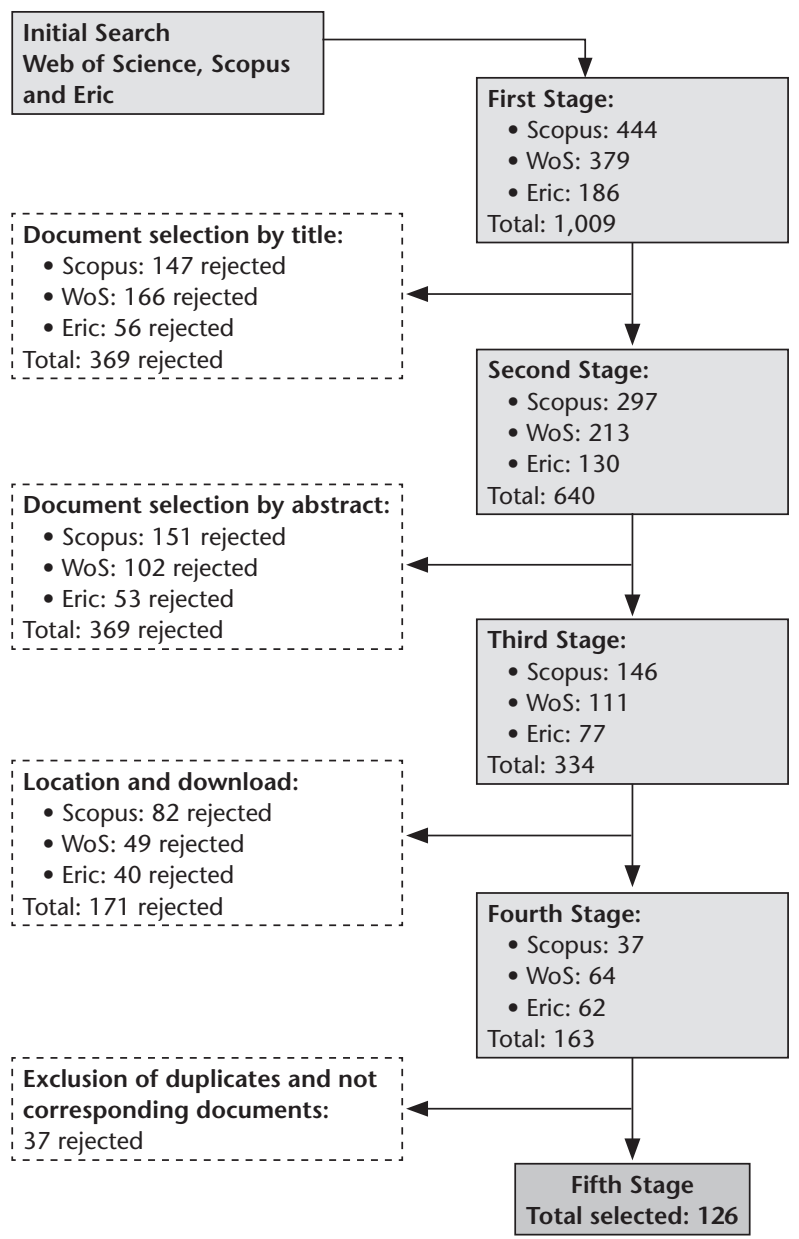

Figure 1. Document selection process. of coding reliability, three researchers collaborated on the coding procedure. Disagreements were resolved via discussions among the researchers.

\section{Literature analysis}

Once the 126 documents had been selected, we proceeded with the analysis by entering the data into the qualitative analysis software programme ATLAS.ti. We then went on to highlight and code the documents by the keywords related to the research questions presented earlier.At the same time, the information was coded and entered into a data table of characteristics (table 1).

From an analytical point of view, this study has divided the published DC-related papers into three types: (1) those dealing with DC evaluation, (2) those focusing on the DC development process, and (3) those analysing the DC literature.

The category with the most articles was evaluation, which accounted for 57 (45.24\%) of all the articles selected. Next came those focusing on DC development, accounting for 39 (30.95\%) of the total number. Finally, 20 of the documents included (15.87\%) focus on the literature. This leaves 10 documents (7.94\%) which we did not classify because there was no clear link between them (Figure 2).

Table 1. Document overview

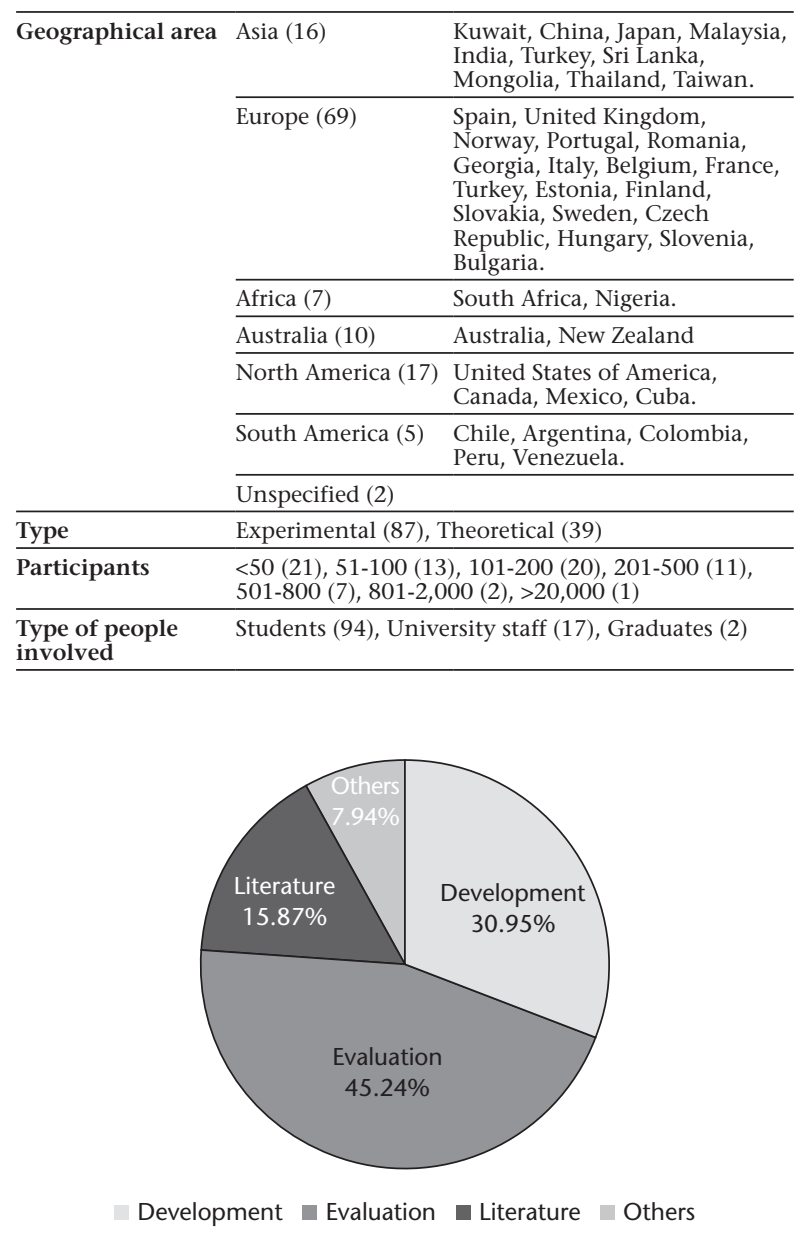

Figure 2. Types of DC-related documents published. 


\section{Results}

\section{What terminology is used to describe DC in higher education and what elements does it consist of?}

The presentation of the results begins with the most frequently-used terms in all the various documents. The aim here is to provide an overview of the terminology used to talk about digital competence in previous studies. It is clear that a number of different terms are used and that many authors use multiple terms within the same text. Table 2 shows these terms, along with the authors that use them. Authors may appear more than once because, as mentioned, they sometimes use more than one term to refer to DC.

Regardless of the terminology used to define the concept, a number of authors agree that DC goes beyond mere technological skills (Cardoso \& Oliveira, 2015). When dealing with ICT, you not only to master certain technological aspects, but also to adopt a critical and confident attitude (Cardoso \& Oliveira, 2015). Being digitally competent, means having a set of skills and attitudes encompassing both technical aspects and a complex degree of multiple literacy (Durán et al., 2016). This literacy means having the ability to access, identify, understand, create, communicate and compute data from diverse sources (Loureiro et al., 2012; Olsson \& Edman-Stålbrant, 2008).

Different authors have identified a range of elements or "literacies" that make up DC. Nevertheless, many of them talk about the same concepts. It is im-

Table 2. Terminology used in the documents analysed

\begin{tabular}{|c|c|}
\hline Term & Authors \\
\hline $\begin{array}{l}\text { ICT competences } \\
(n=6)\end{array}$ & $\begin{array}{l}\text { Albertos, Domingo, \& Albertos (2016) } \\
\text { Guitert, Romeu, Guerrero, \& Padrós (2008) } \\
\text { Puchmüller \& Puebla (2014) } \\
\text { Schreiber (2015) } \\
\text { Senkbeil \& Ihme (2017) } \\
\text { Starčič, Cotic, Solomonides, \& Volk (2016) }\end{array}$ \\
\hline $\begin{array}{l}\text { Digital competence } \\
(\mathrm{n}=31)\end{array}$ & $\begin{array}{l}\text { Albertos et al., (2016) } \\
\text { Chan \& Chiu (2017) } \\
\text { Demchenko (2016) } \\
\text { Eizaguirre, Altuna, Pikabea, Marko, \& Pérez (2017) } \\
\text { Deumal \& Guitert (2015) } \\
\text { Durán, Gutiérrez, \& Prendes (2016) } \\
\text { Flores \& Roig (2016) } \\
\text { Gabarda, Rodríguez, \& Moreno (2017) } \\
\text { Gutiérrez \& Serrano (2016) } \\
\text { Guzmán-Simón, García-Jiménez, \& López-Cobo } \\
\text { (2017) } \\
\text { Jiménez-Cortés, Vico-Bosch, \& Rebollo-Catalán } \\
\text { (2017) } \\
\text { Korucu, Yucel, Gundogdu, \& Gencturk (2016) } \\
\text { Liesa-Orús, Vázquez-Toledo, \& Lloret-Gazo (2016) } \\
\text { Maderick, Zhang, Hartley, \& Marchand (2015) } \\
\text { Mattila (2016) } \\
\text { Mehran, Alizadeh, Koguchi, \& Takemura (2017) } \\
\text { Mengual-Andrés, Roig-Vila, \& Mira (2016) } \\
\text { Mesároš \& Mesároš (2010) } \\
\text { Mirete Ruiz (2016) } \\
\text { Morellato (2014) } \\
\text { Moreno \& Delgado (2013) } \\
\text { Peña-López (2010a) } \\
\text { Pérez-Mateo, Romero, \& Romeu-Fontanillas } \\
\text { (2014) } \\
\text { Rocha \& BehAlejandra (2014) } \\
\text { Romero-rodríguez, Torres-toukoumidis, Pérez, \& } \\
\text { Aguaded (2016) } \\
\text { Rubilar, Alveal, \& Fuentes (2017) } \\
\text { Saalman (2011) } \\
\text { Starčič et al., (2016) } \\
\text { Simonics (2017) } \\
\text { Simonics (2013) } \\
\text { Tsankov \& Damyanov (2017) }\end{array}$ \\
\hline
\end{tabular}

Table 2. Terminology used in the documents analysed (continuation)

\begin{tabular}{|c|c|}
\hline Term & Authors \\
\hline $\begin{array}{l}\text { Information literacy } \\
(n=11)\end{array}$ & $\begin{array}{l}\text { Alfonzo \& Batson (2014) } \\
\text { Alqudsi-ghabra \& Al-Dousari (2014) } \\
\text { Altınay et al., (2016) } \\
\text { Eisenderg (2011) } \\
\text { Grandal, Reyes, \& Sarría (2012) } \\
\text { Hanbidge, Sanderson, \& Tin (2015) } \\
\text { Holt et al., (2006) } \\
\text { Kolle (2017) } \\
\text { Luckman (2009) } \\
\text { Perez et al., (2007) } \\
\text { Sparks, Katz, \& Beile (2016) }\end{array}$ \\
\hline $\begin{array}{l}\text { Digital literacy } \\
(n=56)\end{array}$ & 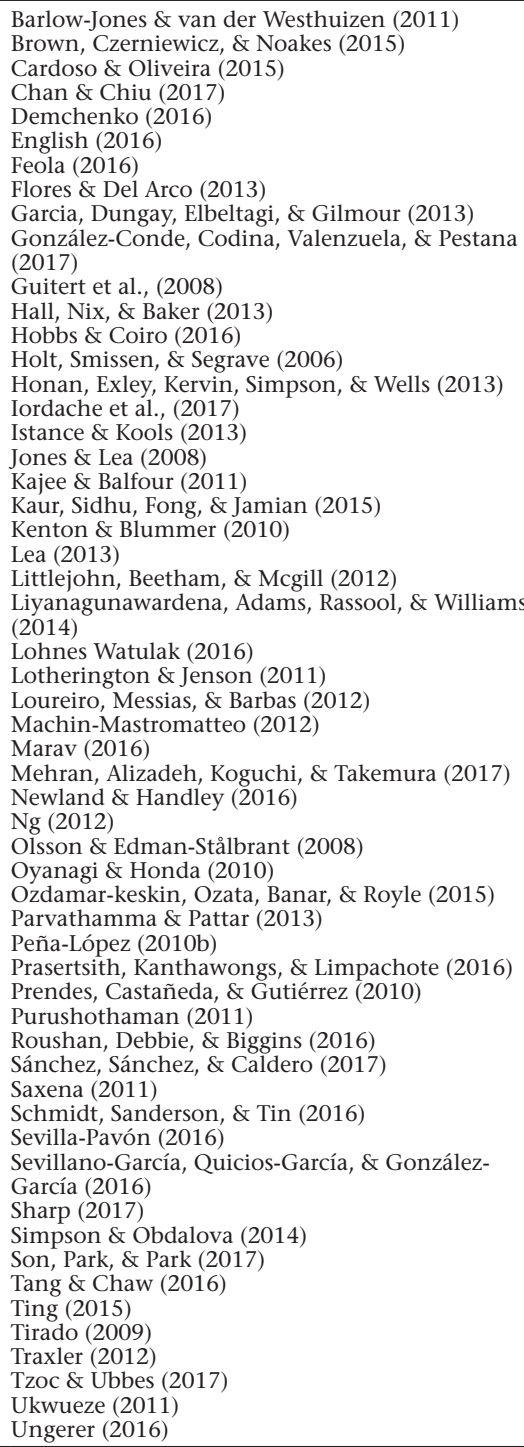 \\
\hline $\begin{array}{l}\text { Computer literacy } \\
(\mathrm{n}=2)\end{array}$ & $\begin{array}{l}\text { Brown et al., (2015) } \\
\text { Perez, Murray, \& Myers (2007) }\end{array}$ \\
\hline e-literacy $(n=2)$ & $\begin{array}{l}\text { Demchenko (2016) } \\
\text { Loureiro et al., (2012) }\end{array}$ \\
\hline ICT literacy $(n=2)$ & $\begin{array}{l}\text { Eisenderg (2011) } \\
\text { Goodfellow (2011) }\end{array}$ \\
\hline Media literacy $(n=3)$ & $\begin{array}{l}\text { Hallaq (2016) } \\
\text { Luckman (2009) } \\
\text { Reedy, Boitshwarelo, Barnes, \& Billany (2015) }\end{array}$ \\
\hline Digital skills $(n=8)$ & $\begin{array}{l}\text { Epure \& Mihaes (2015) } \\
\text { Montoro, Hinojo-Lucena, \& Sánchez (2015) } \\
\text { Peña-López (2010a) } \\
\text { Peña-López (2010b) } \\
\text { Reedy et al. (2015) } \\
\text { Romero-rodríguez et al., (2016) } \\
\text { Sánchez et al., (2017) } \\
\text { Turcsányi-Szabó (2012) }\end{array}$ \\
\hline Skills with ICT $(\mathrm{n}=3)$ & $\begin{array}{l}\text { Gill, Dalgarno, \& Carlson (2015) } \\
\text { Simpson \& Obdalova (2014) } \\
\text { Sparks et al., (2016) }\end{array}$ \\
\hline $\begin{array}{l}21^{\text {st }} \text {-century skills } \\
(\mathrm{n}=1)\end{array}$ & Kivunja (2015) \\
\hline $\begin{array}{l}\text { Digital proficiency } \\
(n=1)\end{array}$ & Mabila, Gelderblom, \& Ssemugabi (2014) \\
\hline
\end{tabular}


portant to stress that the results below include all the terms relating to DC uncovered in the analysis of all the documents that mention these concepts, regardless of the specific terminology used in a given document. These concepts are (Figure 3): (1) Information skills $(\mathrm{n}=18)$. This term is defined as the ability to search for, access, manage, understand, secure and classify content found in different formats on the web (Senkbeil \& Ihme, 2017; Ungerer, 2016); (2) Content creation/ media skills $(n=11)$. This is the ability to create and edit new content in different formats (audio, video, text ...) by integrating the available information (Deumal \& Guitert, 2015; Loureiro et al., 2012); (3) Communication $(n=11)$. This refers both to communicating via digital tools with other members of online platforms and to the capacity to collaborate and network (Gutiérrez \& Serrano, 2016; Son et al., 2017); (4) Ethical skills $(n=2)$. This is ability to understand the rules relating to the ownership of content and relations with other participants in the network (Cardoso \& Oliveira, 2015; Hallaq, 2016); (5) Problem solving ( $n=3)$. This concept refers to the ability to solve problems generated by the use of digital tools or problems arising as part of this use itself (Deumal \& Guitert, 2015; Morellato, 2014); (6) Technical skills/use $(n=12)$. This refers to access to digital tools and to having the technical knowledge needed to use them (Cózar, De Moya, Hernández, \& Hernández Bravo, 2016; Moreno \& Delgado, 2013); (7) Strategic skills $(n=2)$. This is the ability to apply the other digital skills listed here to achieve personal and professional success (Iordache et al., 2017; Senkbeil \& Ihme,2017).

It should be highlighted that the concepts are not perceived as being totally separate from one another. It is common to relate abilities. Information abilities, for example, are associated with content creation and communication skills. Another common factor is that most documents dealing with DC focus on information literacy (Kaur et al., 2015; Loureiro et al., 2012; Morellato, 2014; Ozdamar-keskin et al., 2015; Son et al., 2017). Meanwhile, it seems clear that there is a strong link between problem solving and strategic skills. Gutiérrez \& Serrano (2016) have argued that problem solving is the most cross-cutting skill, while Iordache et al. (2017) approach strategic skills from a more comprehensive perspective, addressing how they affect everyday success. Both of these publications talk about

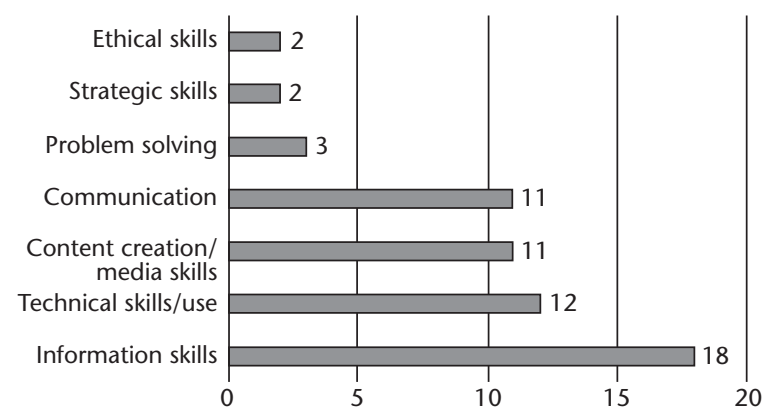

Figure 3. DC elements: frequency of use. using technologies for personal development and to find solutions.

From all this, it can be seen that most DC elements are interlinked and are not mutually exclusive categories, but complementary concepts.

\section{What DC-related profile do the students have?}

One of the most common discussions about students concerns their digital competence. There has been a great deal of scholarly interest in the issue of whether or not they are in fact digital natives, as defined by Prensky (2001 \& 2007). Various papers take the opposite view, concluding that students do not have the required level of DC (Cabezas \& Casillas, 2017) and arguing that, despite being members of a generation classified as digital natives, they are not highly digitally competent at all (Liesa-Orús et al., 2016; Mesároš \& Mesároš, 2010). The fact that they use digital tools does not automatically make them DC. This is especially evident when examining their abilities. Most of the skills they do have are technical, meaning that they need to improve their information and multimedia competences (Ozdamar-keskin et al., 2015; Gabarda et al., 2017).

In addition, there is a gap between university students' formal and informal abilities, with students scoring higher in the latter category (Guzmán-Simón et al., 2017). Most are unable to use specific software during their education (Roushan et al., 2016). They use multimedia tools with great frequency but have little knowledge of the technology or theories behind these technologies (Ting, 2015).

Therefore, being born as a member of a specific generation accustomed to a certain level of technology use does not necessarily define a person as a digital native (Gobel Kano, 2013). Belonging to a younger generation is no guarantee that students have such digital skills (Littlejohn et al., 2012), although many educators do indeed take this for granted. The concept of digital natives is not universal, and consequently it is not possible to be sure that university students are experts in technology (Purushothaman, 2011). It is more a case of students adjusting to the new methods of communication that have emerged in the 21st century (Gutiérrez, Palacios, \& Torrego, 2010).

Nevertheless, and without generalizing, it is important to bear in mind that a number of other factors can also influence DC levels. They include things like socioeconomic factors, language barriers or unbalanced education policies (Barlow-Jones \& van der Westhuizen, 2011). Other elements include students' access to mobile devices and the internet or, as mentioned before, their economic level (Korucu et al., 2016). Access to technology makes it possible to consume information and encourages improvements in literacy skills (Kajee $\&$ Balfour, 2011).

Other studies reach more positive conclusions with regard to students' digital abilities. One example is a publication by Deumal and Guitert (2015), although 
these researchers caution that their results may be rather high because the participants' teachers sometimes have a fairly low DC level and therefore may have a higher perception of their students' levels. Nevertheless, Maderick et al. (2015) and Son et al. (2017) stress that students' self-perception of their own DC is very high. Like these other authors, Liyanagunawardena et al. (2014) found a group of participants with a high level of computer skills, although they point out that they were in the final years of an ICT degree. Gutiérrez and Serrano (2016) believe that their students are digitally competent, but at a basic level.

The young people with the highest levels of DC tend to be on courses involving ICT and are thus predisposed to using digital tools (Brodahl \& Hadjerrouit, 2011). This predisposition is important as regards their development during the first year at university (Barlow-Jones \& Westhuizen, 2011). However, with regard to learning, it has been found students often lack experience in fields such as e-learning (Poulová, Šimonová, \& Černá, 2011). This has an effect on distance learning because, in order to follow a blended learning programme, for example, a good level of DC is necessary (Tang \& Chaw, 2016). Autonomy is needed when it comes to making good use of the technology throughout the learning processes (Buchanan, Sainter, \& Saunders, 2013).

There have been various proposals for improving DC. Starčič et al. (2016) have found that training in the digital field has a positive impact on students' careers. However, there is a need to find out whether today's curricula are coherent with the knowledge that contemporary society demands (Puchmüller \& Puebla, 2014). Various authors highlight the lack of training in the use of technology for information management (Ozdamar-keskin et al., 2015). Indeed, more training in ICT is seen as necessary not only on a small scale, but also as part of a broader transformation (Moreno \& Delgado, 2013). Both learners and teachers need to develop information literacy, and naturally, in order for them to acquire this, they need support materials (Hanbidge et al., 2015).

Educators' practices are not enough ensure that students will develop the competences they need for work in the future (Ungerer, 2016). DC has little presence in cross-curricula (Saalman, 2011). In higher education, there is a need for training programmes that ensure that the development of these competences is transversal (Moreno \& Delgado, 2013). Alternatively, universities could design and implement ICT literacy courses to help students with their expectations and perceptions (Perez et al., 2007).

There is a clear relationship between the non-development of DC and lack of training. Those papers that look at non-digitally competent students also stress that training is needed.

\section{How is DC developed?}

There are several ways in which DC is developed, all of them taking place at both macro and micro levels.
Some of the most popular approaches involve institutional actions made up of plans, courses, curricular changes and other kinds of programmes implemented at a general university level. Students prefer to acquire these abilities in guided subjects (Hall et al., 2013) and expect institutions to give them support during the learning process (Hallaq, 2016).

Higher education plays a key role in students' acquisition of abilities for academic and professional contexts (Pérez-Mateo et al., 2014). Digital literacy can be an important part of curricular innovation (Holt et al., 2006). Its significant integration into the curriculum is perceived as positive by students and educators, as is its appropriateness in their fields of study (English, 2016; Starčič et al., 2016).

However, authors such as Eisenderg (2011) have cast doubt on these statements, arguing that the integration of new content is not realistic. Instead he suggests that content related to digital abilities should be developed more.

Meanwhile, DC is not just about students. It also involves teachers and university staff, and long-term strategies aimed at enhancing the skills of these groups are needed (Littlejohn et al., 2012). These people need training to be able to explore the implications of the concept of literacy (Hobbs \& Coiro, 2016). Continuous access to training is therefore needed (Mattila, 2016). The development of these competences by instructors is necessary because the professionals who acquire them will then be able to teach them to their students (Korucu et al., 2016). Also, it is the responsibility of the institution to promote the use of technologies by its members (Puchmüller \& Puebla, 2014).

There are also strategies with a more direct application. ICT learning is understood in different ways. Different practices and formats enable students to complete training at various levels (Guzmán-Simón et al., 2017). Strategies include: (1) encouraging awareness of Personal Learning Environment, which makes it easier to take control of self-education (Aguilar-Peña, Rus-Casas, Muñoz-Rodríguez, Jiménez-Torres, \& PeñaHita, 2016), (2) e-learning, taking into account various factors such as content, materials and even access to technology (Liyanagunawardena et al., 2014), (3) mobile devices that transcend space-time barriers (Schmidt et al., 2016), (4) digital storytelling activities that motivate students to learn by creating personal stories that require multimodal skills (Chan \& Chiu, 2017), and (5) the use of Twitter, which has improved students' capacity for critical analysis, editing and writing (Barnard, 2016).

Regardless of how which knowledge is transmitted, it must be adapted to the students' needs and previous learning (Eizaguirre et al., 2017). Working autonomously, students can see their achievements and gain confidence in themselves (Kivunja, 2015). The role of the teacher in these situations is as content facilitator and guide (Turcsányi-Szabó, 2012), one who promotes collaboration with other university resources (Turcsányi-Szabó, 2012; Tzoc \& Ubbes, 2017). As mentioned 
above, it is the educator's role to interconnect students and experts in order for new content to be created (Morellato, 2014)

Last but not least, another point is that for DC to be developed correctly there must be access to technology. This is the responsibility of the institutions and/ or the state, who must work to put these tools within students' reach. Therefore, help with access and a more radical approach to technologies in the curriculum are required (Arkansas Department of Education, 2008; Ukwueze, 2011).

\section{Discussion}

Now that the documents in the dataset have been reviewed, the results need to be discussed in the light of the initial assumptions described in the introduction. As far as the terminology is concerned, this depends on the author. The most frequently-used terms are "digital literacy" and "digital competence", in that order. Regardless of the nomenclature chosen, the concepts incorporate the idea that being competent or literate in a digital context involves a combination of skills and attitudes (Durán et al., 2016; Loureiro et al., 2012; Olsson \& Edman-Stålbrant, 2008).

The account of the elements that make up this competence also vary depending on the author. However, the most frequently-used terms are those that refer to information and the ability to find, assess, store and understand it (Cardoso \& Oliveira, 2015; PeñaLópez, 2010b), to technical skills, both in terms of their use (as indicated by Olsson \& Edman-Stålbrant (2008)) and in terms of access (Loureiro et al., 2012), to communication via networks and the creation of content in different formats (Morellato, 2014), and finally and less frequently, as Deumal \& Guitert (2015) have observed, to abilities related to problem solving, i.e. those which, according to Hallaq (2016), are related to ethical questions, or those that enable students to apply the technologies to their everyday lives (Iordache et al., 2017; Senkbeil \& Ihme, 2017). Most of these general concepts match those in DigComp 2.1 (Carretero, Vuorikari \& Punie, 2017), the framework created by the Institute for Prospective Technological Studies (IPTS) to update the earlier Digcomp 2.0 (Vuorikari, Punie, Carretero \& Brande, 2016) and Digcomp (Ferrari, 2012).

Using a variety of the above elements and other criteria specific to individual research projects, many DC evaluation tools have been designed. These include those by English (2016) and Flores \& Roig (2016), whose research focuses on the assessment of DC levels.

There is no clear answer to the question concerning students' level of DC. Most of the authors believe that, despite the characterisation of the current generation of students as digital natives, they do not have a high level of digital competence (Liesa-Orús et al., 2016; Mesároš \& Mesároš, 2010). However, it should not be forgotten that there are many student profiles and many factors influence their abilities, including access and economic level (Korucu et al., 2016). The only thing that is clear is that training in this area has a positive impact (Starčič et al., 2016).

There are also a wide range of ideas as regards what kind of training is best. Authors such as Hall et al. (2013) and Hallaq (2016) argue that students prefer to receive training inside their educational institutions and receive help from them. It would therefore be a good idea to integrate this training into the curriculum, even in a cross-curriculum manner (English, 2016; Starčič et al., 2016). Training for university staff and educators is also important because they have a key role in transmitting knowledge to students (Hobbs \& Coiro, 2016; Littlejohn et al., 2012). And it is certainly important to bear in mind the particular knowledge and needs of the undergraduate (Eizaguirre et al., 2017; Ukwueze, 2011).

\section{Conclusions, limitations and future research}

All the above leads us to conclude that there is a long way to go as regards the consensus on the terminology and the different elements that make up DC. Work therefore needs to be done to unify and clarify the concept, and also to create an appropriate development strategy for youth education in this area. This is clearly necessary for these students' futures, especially considering that most of the documents do not show that the students have acquired an adequate level of DC. Also, it is important to emphasize the DC development in university staff and educators and to adapt their training to the pace of technological evolution. However, the main focus of these papers is evaluation and not development.

Like all research, this work also has several limitations, and the results need to be interpreted with this in mind. First, the inclusion criteria that guided the selection of studies for this review could have influenced the results. Some relevant studies may have been excluded. Secondly, the 126 documents which were included in the final selection were not distributed equitably across countries and regions. Most were from Europe, which means we cannot draw conclusions globally. Also, future research will need to include the new terms used within the various documents considered.

In conclusion, this is a good start along the path toward finding out more about students and their DC according to the literature, but more work needs to be done in this field.

\section{References}

Aguilar-Peña, J. D., Rus-Casas, C., Muñoz-Rodríguez, F., Jiménez-Torres, M., \& Peña-Hita, M. (2016). Educational applications that promote personal learning environments (PLE). In Technologies Applied to Electronics Teaching, TAEE 2016 (pp. 1-6). https://doi. org/10.1109/TAEE.2016.7528367

Albertos, A., Domingo, À., \& Albertos, J. E. (2016). Teaching strategy for the development of digital skills 
in the university classroom: From recreational use to training use. Educar, 5(2), 243-261. https://doi.org/ 10.5565/rev/educar.732

Alfonzo, P. M., \& Batson, J. (2014). Utilizing a Coteaching model to enhance digital literacy instruction for doctoral students. International Journal of Doctoral Studies, 9, 61-71.

Alqudsi-ghabra, T., \& Al-Dousari, E. (2014). Internet Use Among Incoming Undergraduate Students of Kuwait University. Journal of Information \& Knowledge Management, 13(02). https://doi.org/10.1142/ S0219649214500178

Altınay, Z., Ossiannilsson, E., Kalaç, M. O., Başarı, G., Aktepebaşı, A., \& Altınay, F. (2016). Establishing a framework on OER practices for ICT competence of disabled citizens. Turkish Online Journal of Educational Technology, 15(3), 68-72.

Arkansas Department of Education. (2008). Technology Plan 2008-2012.

Barlow-Jones, G., \& Westhuizen, D. (2011). Situating the student: Factors contributing to success in an Information Technology course. Educational Studies, 37(3), 303-320. https://doi.org/10.1080/03055698.2 010.506329

Barnard, J. (2016). Tweets as microfiction: On Twitter's live nature and 140-character limit as tools for developing storytelling skills. New Writing, 13(1), 3-16. https://doi.org/10.1080/14790726.2015.1127975

Brodahl, C., \& Hadjerrouit, S. (2011). Collaborative Writing with Web 2.0 Technologies: Education Students' Perceptions. Journal of Information Technology Education, 10, 1-31.

Brown, C., Czerniewicz, L., \& Noakes, T. (2015). Online content creation: looking at students' social media practices through a Connected Learning lens Cheryl. Learning, Media and Technology, 41(1), 140-159.

Buchanan, T., Sainter, P., \& Saunders, G. (2013). Factors affecting faculty use of learning technologies: Implications for models of technology adoption. Journal of Computing in Higher Education, 25(1), 1-11. https:// doi.org/10.1007/s12528-013-9066-6

Bullen, M., Morgan, T., \& Qayyum, A. (2011). Digital learners in higher education: Generation is not the issue. Canadian Journal of Learning and Technology/La revue canadienne de l'apprentissage et de la technologie, $37(1)$.

Cabezas, M., \& Casillas, S. (2017). Are Future Social Educators Digital Residents? Revista Electronica de Investigacion Educativa, 19(4), 61-72.

Cardoso, P. A., \& Oliveira, N. R. (2015). Scholars ' use of digital tools : open scholarship and digital literacy. In Proceedings of the 9th International Technology, Education and Development Conference (INTED2015), (pp. 5756-5763).

Carretero, Vuorikari \& Punie (2017) DigComp 2.1: The Digital Competence Framework for Citizens. Luxembourg: Publications Office of the European Union.

Chan, B., \& Chiu, T. (2017). Digital Literacy Learning In Higher Education Through Digital Storytelling Approach. Journal of International Education Research, 13(1), 1-16.
Cózar, R., De Moya, M. V, Hernández, J. A., \& Hernández, J. R. (2016). Conocimiento Y Uso De Las Tecnologías De La Información Y Las Comunicaciones (TIC) Según El Estilo De Aprendizaje De Los Futuros Maestros. Formación Universitaria, 9(13), 105-118. https://doi.org/10.4067/S0718-50062016000600010

Demchenko, I. (2016). Forming of future teachers' ict -competence: canadian experience. Comparative Professional Pedagogy, 6(1), 54-60.

Deumal, G., \& Guitert, M. (2015). La competencia digital en la enseñanza del diseño. El caso de BAU Digital competence in design education. Revista Latinoamericana de Tecnología Educativa, 14(2), 51-65.

Durán, M., Gutiérrez, I., \& Prendes, M. P. (2016). Análisis conceptual de modelos de competencia digital del profesorado universitario. RELATEC: Revista Latinoamericana de Tecnología, 15(1), 97-114. https:// doi.org/10.17398/1695

Eisenderg, M. B. (2011). Develop and Deliver Essential Information Literacy Programs. Journal of the Korean Society for Library and Information Science, 45(2), 5-21. https://doi.org/10.4275/KSLIS.2011.45.2.005

Eizaguirre, A., Altuna, J., Pikabea, I., Marko, J., \& Pérez, V. (2017). Las competencias transversales en el grado de Pedagogía: diagnóstico y estado de la cuestión. Revista de Docencia Universitaria, 15(1), 259-276.

English, J. A. (2016). A Digital Literacy Initiative in Honors: Perceptions of Students and Instructors about its Impact on Learning and Pedagogy. Journal of the National Collegiate Honors Council, 17(2), 125-155.

Epure, M., \& Mihaes, L. C. (2015). Adapting teaching and learning to the labour market requirements - a romanian case study. In Edulearn15: 7th International Conference on Education and New Learning Technologies, (pp. 2911-2919).

Feola, E. I. (2016). Digital Literacy and New Technological Perspectives. Universal Journal of Educational Research, 4(9), 2174-2180. https://doi.org/10.13189/ ujer.2016.040929

Ferrari, A. (2012). Digital competence in practice: An analysis of frameworks. Sevilla: European Commission, Joint Research Centre (JRC).

Flores, O., \& Del Arco, I. (2013). Nativos digitales, inmigrantes: rompiendo mitos. Un estudio sobre el dominio de las TIC en profesorado y estudiantado de la universidad de Lleida. Bordon Revista de Pedagogia. Sociedad Española de Pedagogía, 65(2), 59-74. https://doi.org/10.13042/brp.2013.65204

Flores, C., \& Roig, R. (2016). Perception of students of Education on the development of their digital competence throughout their learning process. Estudios Pedagógicos XLII, 3, 129-148. https://doi.org/10.4067/ S0718-07052016000400007

Gabarda, V., Rodríguez, A., \& Moreno Rodríguez, M. D. (2017). La competencia digital en estudiantes de magisterio. Análisis competencial y percepción personal del futuro maestro. Educatio Siglo XXI, 35, 253274. https://doi.org/10.6018/j/298601

Gallardo-Echenique, E. E., Marqués-Molías, L., Bullen, M., \& Strijbos, J. W. (2015). Let's talk about digital 
learners in the digital era. The International Review of research in open and distributed learning, 16(3), 156187.

Garcia, E., Dungay, K., Elbeltagi, I., \& Gilmour, N. (2013). An evaluation of the impact of academic staff digital literacy on the use of technology: A case study of uk higher education. In Proceedings of EDULEARN13 Conference, (pp. 2042-2051).

Gill, L., Dalgarno, B., \& Carlson, L. (2015). How Does Pre-Service Teacher Preparedness to Use ICTs for Learning and Teaching Develop Through Their Degree Program? Australian Journal of Teacher Education, 40(1), 36-59. https://doi.org/10.14221/ajte.2015 v40n1.3

Gisbert, M., González, J., \& Esteve, F. (2016). Competencia digital y competencia digital docente: una panorámica sobre el estado de la cuestión. Revista Interuniversitaria de Investigación En Tecnología Educativa, O(Junio), 74-83. https://doi.org/10.6018/ RIITE2016/257631

Gobel, P., \& Kano, M. (2013). Student and Teacher Use of Technology at the University Level. In IADIS International Conference on Cognition and Exploratory Learning in Digital Age, (pp. 17-24).

González-Conde, J., Codina, N., Valenzuela, R., \& Pestana, J. V. (2017). Critical analysis and digital literacy in learning social psychology. In Proceedings of the 3rd International Conference on Higher Education Advances, (pp. 1052-1059). https://doi.org/10.4995/ HEAD17.2017.5513

González, I. F., Urrútia, G., \& Alonso-Coello, P. (2011). Revisiones sistemáticas y metaanálisis: bases conceptuales e interpretación. Revista Española de Cardiología, 64(8), 688-696.

Goodfellow, R. (2011). Literacy, literacies and the digital in higher education. Teaching in Higher Education, 16(1), 131-144. https://doi.org/10.1080/13562517.2 011.544125

Grandal, O., Reyes, S. Á., \& Sarría, E. (2012). Procesos de alfabetización informacional en la educación superior. Revista Habanera de Ciencias Médicas, 11(4), 537-545. Retrieved from http://scielo.sld.cu

Guitert, M., Romeu, T., Guerrero, A. E., \& Padrós, A. (2008). ICT competences for net generation students. In Proceedings - The 8th IEEE International Conference on Advanced Learning Technologies, ICALT 2008, (pp. 480-481). https://doi.org/10.1109/ICALT.2008.267

Gutiérrez, A., Palacios, A., \& Torrego, L. (2010). Tribus digitales en las aulas universitarias. Comunicar, 17(34), 173-181. https://doi.org/10.3916/C34-201003-17

Gutiérrez, I., \& Serrano, J. L. (2016). Evaluación y desarrollo de la competencia digital de futuros maestros en la Universidad de Murcia. Journal of New Approaches in Educational Research, 6(1), 51-56. https://doi. org/10.7821/naer.2016.1.152

Guzmán-Simón, F., García-Jiménez, E., \& López-Cobo, I. (2017). Undergraduate students' perspectives on digital competence and academic literacy in a Spanish University. Computers in Human Behavior, 74,
196-204. https://doi.org/10.1016/j.chb.2017.04.040

Hall, M., Nix, I., \& Baker, K. (2013). Student experiences and perceptions of digital literacy skills development: engaging learners by design?. The Electronic Journal of E-Learning, 11(3), 207-225.

Hallaq, T. (2016). Evaluating Online Media Literacy in Higher Education: Validity and Reliability of the Digital Online Media Literacy Assessment (DOMLA). Journal of Media Literacy Education, 8(1), 62-84.

Hanbidge, A. S., Sanderson, N., \& Tin, T. (2015). Using mobile technology to enhance undergraduate student digital information literacy skills : A canadian case study. The IAFOR Journal of Education, 3(2), 108121.

Hobbs, R., \& Coiro, J. (2016). Everyone Learns from Everyone: Collaborative and Interdisciplinary Professional Development in Digital Literacy. Journal of Adolescent and Adult Literacy, 59(6), 623-629. https:// doi.org/10.1002/jaal.502

Holt, D., Smissen, I., \& Segrave, S. (2006). New students, new learning, new environments in higher education: Literacies in the digital age. In Proceedings of the 23rd annual ascilite conference: Who's learning? Whose technology?, (pp. 327-337).

Honan, E., Exley, B., Kervin, L., Simpson, A., \& Wells, M. (2013). Rethinking the Literacy Capabilities of Pre-Service Primary Teachers in Testing Times. Australian Journal of Teacher Education, 38(10), 48-63. https://doi.org/10.14221/ajte.2013v38n10.3

Iordache, C., Mariën, I., Baelden, D., Iordache, C., Mariën, I., \& Baelden, D. (2017). Developing Digital Skills and Competences: A Quick-Scan Analysis of 13 Digital Literacy Models. Italian Journal of Sociology of Education, 9(91), 6-30. https://doi.org/10.14658/ pupj-ijse-2017-1-2

Istance, D., \& Kools, M. (2013). OECD Work on Technology and Education: innovative learning environments. European Journal of Education, 48(1), 43-57.

Jiménez-Cortés, R., Vico-Bosch, A., \& Rebollo-Catalán, A. (2017). Female university student's ICT learning strategies and their influence on digital competence. International Journal of Educational Technology in Higher Education, 14(1), 2-12. https://doi.org/10.1186/ s41239-017-0040-7

Jones, S., \& Lea, M. R. (2008). Digital literacies in the lives of undergraduate students: exploring personal and curricular spheres of practice. The Electronic Journal of E-Learning, 6(3), 207-216.

Kajee, L., \& Balfour, R. (2011). Students' access to digital literacy at a South African university: Privilege and marginalisation. Southern African Linguistics and Applied Language Studies, 29(2), 187-196. https://doi. org/10.2989/16073614.2011.633365

Kaur, S., Sidhu, G. K., Fong, L. L., \& Jamian, L. S. (2015). Supervisory and digital literacy practices in postgraduate supervision: A case study. In Proceedings of the 12th International Conference on Cognition and Exploratory Learning in the Digital Age, CELDA 2015, (pp. 35-42).

Kennedy, G., Dalgarno, B., Bennett,... Chang, R. (2009). Educating the net generation. A handbook of findings for 
practice and policy. Australia: Australian Learning \& Teaching Council.

Kenton, J., \& Blummer, B. (2010). Promoting digital literacy skills: Examples from the literature and implications for academic librarians. Community and Junior College Libraries, 16(2), 84-99. https://doi. org/10.1080/02763911003688737

Kivunja, C. (2015). Teaching Students to Learn and to Work Well with 21st Century Skills: Unpacking the Career and Life Skills Domain of the New Learning Paradigm. International Journal of Higher Education, 4(1), 1-11. https://doi.org/10.5430/ijhe.v4n1p1

Kolle, S. R. (2017). Global research on information literacy: a bibliometric analysis from 2005 to 2014 . The Electronic Library, 35(2), 283-298. https://doi. org/10.1108/EL-08-2015-0160

Korucu, A. T., Yucel, A., Gundogdu, M. M., \& Gencturk, T. (2016). Investigation the Technology Usage Level of Teacher Candidates. Participatory Educational Research, 3(1), 14-21. https://doi.org/10.17275/per. 15.49.3.1

Lea, M. R. (2013). Reclaiming literacies: Competing textual practices in a digital higher education. Teaching in Higher Education, 18(1), 106-118. https://doi. org/10.1080/13562517.2012.756465

Liesa-Orús, M., Vázquez-Toledo, S., \& Lloret-Gazo, J. (2016). Identificación de las fortalezas y debilidades de la competencia digital en el uso de aplicaciones de internet del alumno de primer curso del Grado de Magisterio. Revista Complutense de Educacion, 27(2), 845-862. https://doi.org/10.5209/rev_RCED.2016. v27.n2.48409

Littlejohn, A., Beetham, H., \& Mcgill, L. (2012). Learning at the digital frontier: A review of digital literacies in theory and practice. Journal of Computer Assisted Learning, 28(6), 547-556. https://doi.org/ 10.1111/j.1365-2729.2011.00474.x

Liyanagunawardena, T. R., Adams, A. A., Rassool, N., \& Williams, S. A. (2014). Developing government policies for distance education: Lessons learnt from two Sri Lankan case studies. International Review of Education, 60(6), 821-839. https://doi.org/10.1007/ s11159-014-9442-0

Lohnes Watulak, S. (2016). Reflection in action: using inquiry groups to explore critical digital literacy with pre-service teachers. Educational Action Research, 24(4), 503-518. https://doi.org/10.1080/09650792.2 015.1106957

Lotherington, H., \& Jenson, J. (2011). Teaching multimodal and digital literacy in L2 settings: New literacies, new basics, new pedagogies. Annual Review of Applied Linguistics, 31, 226-246. https://doi. org/10.1017/S0267190511000110

Loureiro, A., Messias, I., \& Barbas, M. (2012). Embracing Web 2.0 \&amp; 3.0 Tools to Support Lifelong Learning - Let Learners Connect. Procedia - Social and Behavioral Sciences, 46, 532-537. https://doi.org/ 10.1016/j.sbspro.2012.05.155

Luckman, S. (2009). New information literacies: Helping university students critically evaluate informa- tion online. International Journal of Learning, 16(6), 499-512. https://doi.org/10.18848/1447-9494/CGP/ v16i06/46384

Mabila, J., Gelderblom, H., \& Ssemugabi, S. (2014). Using eye tracking to investigate first year students' digital proficiency and their use of a learning management system in an open distance environment. African Journal of Research in Mathematics, Science and Technology Education, 18(2), 151-163. https://doi.org /10.1080/10288457.2014.928449

Machin-Mastromatteo, J. (2012). Participatory action research in the age of social media: literacies, affinity spaces and learning. New Library World, 113(11/12), 571-585. https://doi.org/10.1108/03074801211282939

Maderick, J. A., Zhang, S., Hartley, K., \& Marchand, G. (2015). Preservice Teachers and Self-Assessing Digital Competence. Journal of Educational Computing Research, 54(3), 326-351. https://doi.org/10.1177/ 0735633115620432

Marav, D. (2016). Mongolian students' digital literacy practices: The interface between english and the internet. Trabalhos Em Linguística Aplicada, 55(2), 293 - 318 . https://doi.org/10.1590/ 010318134962176441

Mattila, A. (2016). The future educator skills in the digitization era: Effects of technological development on higher education. In Proceedings - 2015 5th International Conference on e-Learning, ECONF 2015, (pp. 212-215). https://doi.org/10.1109/ECONF.2015.18

Mehran, P., Alizadeh, M., Koguchi, I., \& Takemura, H. (2017). Are Japanese digital natives ready for learning english online? a preliminary case study at Osaka University. International Journal of Educational Technology in Higher Education, 14(1), 8. https://doi. org/10.1186/s41239-017-0047-0

Mengual-Andrés, S., Roig-Vila, R., \& Mira, J. B. (2016). Delphi study for the design and validation of a questionnaire about digital competences in higher education. International Journal of Educational Technology in Higher Education, 3(1), 12. https://doi.org/10.1186/ s41239-016-0009-y

Mesároš, F., \& Mesároš, P. (2010). Digital competencies in process of creating the knowledge company in construction sector. In Proceedings of the 27th ISARC, (pp. 544-550).

Mirete Ruiz, A. B. (2016). El profesorado universitario y las TIC. Análisis de su competencia digital. ENSAYOS. Revista de La Facultad de Educación de Albacete, 31(1), 133-147.

Montoro, M. A., Hinojo-Lucena, F. J., \& Sánchez, F. R. (2015). A study on ICT training among faculty members of spanish faculties of education. New Educational Review, 42(4), 27-39. https://doi.org/10.15804/ tner.2015.42.4.02

Morellato, M. (2014). Digital Competence in Tourism Education: Cooperative-experiential Learning. Journal of Teaching in Travel and Tourism, 14(2), 184-209. https://doi.org/10.1080/15313220.2014.907959

Moreno, G. C., \& Delgado, S. C. (2013). Evaluación de la competencia digital y las actitudes hacia las TIC 
del alumnado universitario. Revista de Investigación Educativa, 31(2), 517-536. https://doi.org/10.6018/ rie.31.2.169271

Newland, B., \& Handley, F. (2016). Developing the digital literacies of academic staff: An institutional approach. Research in Learning Technology, 24(1). https://doi.org/10.3402/rlt.v24.31501

$\mathrm{Ng}, \mathrm{W}$. (2012). Can we teach digital natives digital literacy? Computers and Education, 59(3), 1065-1078. https://doi.org/10.1016/j.compedu.2012.04.016

OCDE. (2018). The future of education and skills: Education 2030. Directorate for Education and Skills-OECD: France.

Okoli, C., \& Schabram, K. (2010). A Guide to Conducting a Systematic Literature Review of Information Systems Research. Working Papers on Information Systems, 10(26), 1-51. http://doi.org/10.2139/ssrn. 1954824

Olsson, L., \& Edman-Stålbrant, E. (2008). Digital literacy as a challenge for Teacher Education. In Learning to Live in the Knowledge Society (pp. 11-18). https:// doi.org/10.1007/978-0-387-09729-9_2

Oyanagi, W., \& Honda, T. (2010). A report on investigation of digital literacies among child, teacher, university student. In Proceedings of the 18th International Conference on Computers in Education: Enhancing and Sustaining New Knowledge Through the Use of Digital Technology in Education, ICCE 2010 (pp. 763-767).

Ozdamar-keskin, N., Ozata, F. Z., Banar, K., \& Royle, K. (2015). Examining digital literacy competences and learning habits of open and distance learners. Contemporary Educational Technology, 6(1), 74-90.

Parvathamma, N., \& Pattar, D. (2013). Digital literacy among student community in management institutes in Davanagere District, Karnataka State, India. Annals of Library and Information Studies.

Peña-López, I. (2010a). Framing the Digital Divide in Higher Education. Revista de Universidad y Sociedad Del Conocimiento, 7(1), 2-6.

Peña-López, I. (2010b). From Laptops to Competences: Bridging the Digital Divide in Education. RUSC. Universities and Knowledge Society Journal, 7(1), 21-32. https://doi.org/10.7238/rusc.v7i1.659

Pérez-Mateo, M., Romero, M., \& Romeu-Fontanillas, T. (2014). Collaborative construction of a project as a methodology for acquiring digital competences. Comunicar, 21(42), 15-23. https://doi.org/10.3916/ C42-2014-01

Perez, J., Murray, M., \& Myers, M. (2007). An Information Technology Literacy Self- Assessment Instrument: Development and Pilot Results. In AMCIS 2007 (p. 229). Retrieved from http://aisel.aisnet.org/ amcis 2007

Poulová, P., Šimonová, I., \& Černá, M. (2011). eLearning and New University Students. Recent Researches in Educational Technologies ELearning, 156-160. Retrieved from http://www.uhk.cz

Prasertsith, A. K., Kanthawongs, P., \& Limpachote, T. (2016). Students' Google Drive Intended Usage: a Case Study of Mathematics Courses in Bangkok
University. In 13th International Conference on Cognition and Exploratory Learning in Digital Age (CELDA 2016) STUDENTS' (pp. 355-338).

Prendes, M. P., Castañeda, L., \& Gutiérrez, I. (2010). Competencias para el uso de TIC de los futuros maestros. Comunicar, 18(35), 175-182. https://doi.org/ 10.3916/C35-2010-03-11

Prensky, M. (2001). Digital natives, digital immigrants part 1. On the horizon, 9(5), 1-6.

Prensky, M. (2007). How to teach with technology: Keeping both teachers and students comfortable in an era of exponential change. Emerging technologies for learning, 2(4), 40-46.

Puchmüller, A. B., \& Puebla, M. M. (2014). TIC en Educación Superior: usos e implicancias en dos carreras de instituciones argentinas. Encuentros Universidad Autónoma Del Caribe, 12(2), 11-23. https://doi. org/10.15665/re.v12i2.266

Purushothaman, A. (2011). Student empowerment through internet usage - a ethnographic action research project in india. In edulearn11: 3rd international conference on education and new learning technologies (pp. 1766-1775).

Redecker, C. \& Punie, Y. (2017). European framework for the digital competence of educators: DigCompEdu. Joint Research Centre.

Reedy, A., Boitshwarelo, B., Barnes, J., \& Billany, T. (2015). Swimming with Crocs: Professional Development in a Northern Context. In The annual conference of the Australian Teacher Education Association (ATEA).

Rocha, L., \& BehAlejandra, P. (2014). E-Competence: The elderly and competence in e-learning. In CSEDU 2014 - Proceedings of the 6th International Conference on Computer Supported Education (Vol. 1, pp. 346-353). https://doi.org/10.5220/0004850003460353

Romero-rodríguez, L. M., Torres-toukoumidis, Á., Pérez, A., \& Aguaded, I. (2016). Analfanauts and Fourth Screen: Lack of Infodiets and Media and Infor-mation Literacy in Latin American University Students. Fonseca, Journal of Comunication, 12, 11-25. https://doi. org/10.14201/fjc2016121125

Roushan, G., Debbie, H., \& Biggins, D. (2016). The Kaleidoscope of Voices: An Action Research Approach to Informin Institutional e-Learnin Policy. Electronic Journal of E-Learning, 14(5), 293-300. Retrieved from www.ejel.org

Rubilar, P. S., Alveal, F. R., \& Fuentes, A. C. M. (2017). Evaluación de la alfabetización digital y pedagógica en TIC, a partir de las opiniones de estudiantes en Formación Inicial Docente. Educação e Pesquisa, 43(1), 127 -143. https://doi.org/10.1590/s 1517 9702201701154907

Saalman, E. (2011). Engineering education teachersedagogical use of digital media shown in projects carried out in a Higher education course: Learning in Digital Media. In WEE 2011 (pp. 41-48).

Sánchez, A., Sánchez, C., \& Caldero, J. (2017). Nuevos modelos tecnopedagógicos. Competencia digital de los alumnos universitarios. Revista Electronica de In- 
vestigacion Educativa, 19(1), 1-9. https://doi. org/10.24320/redie.2017.19.1.1148

Saxena, M. (2011). Reified languages and scripts versus real literacy values and practices: Insights from research with young bilinguals in an Islamic state. Compare, 41(2), 277-292. https://doi.org/10.1080/0 3057925.2011 .547290

Schmidt, A. H., Sanderson, N., \& Tin, T. (2016). Information Literacy on the Go! Adding Mobile To an Age Old Challenge. In 12th International Conference Mobile Learning 2016 (pp. 103-107).

Schreiber, B. R. (2015). "I am what i am": Multilingual identity and digital translanguaging. Language Learning and Technology, 19(3), 69-87.

Senkbeil, M., \& Ihme, J. M. (2017). Motivational factors predicting ICT literacy: First evidence on the structure of an ICT motivation inventory. Computers and Education, 108, 145-158. https://doi.org/10.1016/ j.compedu.2017.02.003

Sevilla-Pavón, A. (2016). Affordances of telecollaboration tools for English for Specific Purposes online learning Ana. World Journal on Educational Technology, 8(3), 218-223.

Sevillano-García, M. L., Quicios-García, M. P., \& González-García, J. L. (2016). The ubiquitous possibilities of the laptop: Spanish university students' perceptions. Comunicar, 24(46), 87-94. https://doi.org/ 10.3916/C46-2016-09

Sharp, L. A. (2017). Enhancing Digital Literacy and Learning Among Adults With Blogs. Journal of Adolescent and Adult Literacy, 61(2), 191-202. https://doi. org/10.1002/jaal.675

Simonics, I. (2013). Digital competency in higher education. 2013 International Conference on Interactive Collaborative Learning (ICL), (September), 88-91. https://doi.org/10.1109/ICL.2013.6644542

Simonics, I. (2017). Use of ICT equipment by engineer teachers and mentors. In IEEE Global Engineering Education Conference, EDUCON (pp. 527-535). https:// doi.org/10.1109/EDUCON.2017.7942897

Simpson, R., \& Obdalova, O. A. (2014). New Technologies in Higher Education - ICT Skills or Digital Literacy? Procedia - Social and Behavioral Sciences, 154, 104-111. https://doi.org/10.1016/j.sbspro.2014. 10.120

Son, J.-B., Park, S., \& Park, M. (2017). Digital literacy of language learners in two different contexts sangsoon Park, 13(2), 1832-4215.

Sparks, J. R., Katz, I. R., \& Beile, P. M. (2016). Assessing Digital Information Literacy in Higher Education: A Review of Existing Frameworks and Assessments With Recommendations for Next-Generation Assessment. ETS
Research Report Series. https://doi.org/10.1002/ ets 2.12118

Starčič, A. I., Cotic, M., Solomonides, I., \& Volk, M. (2016). Engaging preservice primary and preprimary school teachers in digital storytelling for the teaching and learning of mathematics. British Journal of Educational Technology, 47(1), 29-50. https://doi.org/ 10.1111/bjet. 12253

Tang, C. M., \& Chaw, L. Y. (2016). Digital Literacy: A Prerequisite for Effective Learning in a Blended Learning Environment? The Electronic Journal of E-Learning, 14(1), 54-65.

Ting, Y. L. (2015). Tapping into students' digital literacy and designing negotiated learning to promote learner autonomy. Internet and Higher Education, 26, 25-32. https://doi.org/10.1016/j.iheduc.2015.04.004 Tirado, A. (2009). La alfabetización informacional en la universidad: descripción y categorización según los niveles de integración de ALFIN. Caso Universidad de Antioquia. Revista Interamericana de Bibliotecologia, 33(1), 31-83.

Traxler, J. (2012). Context as text in mobile digital literacy: A European university perspective. In CEUR Workshop Proceedings (Vol. 955, pp. 289-293).

Tsankov, N., \& Damyanov, I. (2017). Education majors' preferences on the functionalities of e-learning platforms in the context of blended learning. International Journal of Emerging Technologies in Learning, 12(5), 202-209. https://doi.org/10.3991/ijet.v12i05.6971

Turcsányi-Szabó, M. (2012). Aiming at sustainable innovation in teacher education - from theory to practice. Informatics in Education, 11(1), 115-130.

Tzoc, E., \& Ubbes, V. A. (2017). The Digital Literacy Partnership Website: Promoting Interdisciplinary Scholarship Between Faculty, Students, and Librarians. New Review of Academic Librarianship, 23(2-3), 195-208. https://doi.org/10.1080/13614533.2017.1 333013

Ukwueze, F. N. (2011). Influence of home media technologies on academic performance of undergraduates. Journal of Home Economics Research, 14, 255-262.

Ungerer, L. M. (2016). Digital Curation as a Core Competency in Current Learning and Literacy: A Higher Education Perspective. The International Review of Research in Open and Distributed Learning, 17(5). https://doi.org/10.19173/irrodl.v17i5.2566

Vangrieken, K., Dochy, F., Raes, E., \& Kyndt, E. (2015). Teacher collaboration: A systematic review. Educational Research Review, 15, 17-40.

Vuorikari, R., Punie, Y., Carretero, S., \& Van den Brande, L. (2016). DigComp 2.0: The digital competence framework for citizens. 